\title{
Chapter 4 \\ Monsters, Laws of Nature, and Teleology in Late Scholastic Textbooks
}

\author{
Silvia Manzo
}

By revealing the precariousness of the stability to which life has habituated us -yes, merely habituated, even though we have turned this habit into a law - themonster bestows upon the repetition of species, upon morphological regularity, and upon successful structuration a value all the more eminent in that we can now grasp their contingency.

Canguilhem (2008) 135

In the period of emergence of early modern science, "monsters" or individuals with physical congenital anomalies were considered as rare events which required special explanations entailing assumptions about the laws of nature. This concern with monsters was shared by representatives of the new science and Late Scholastic authors of university textbooks. This paper will reconstruct the main theses of the treatment of monsters in Late Scholastic textbooks, by focusing on the question as to how their accounts conceived nature's regularity and teleology. It shows that they developed a naturalistic teratology in which, in contrast to the naturalistic explanations usually offered by the new science, finality was at central stage. This general point does not impede our noticing that some authors were closer to the views emerging in the Scientific Revolution insofar as they conceived nature as relatively autonomous from God and gave a relevant place to efficient secondary causation. In this connection, this paper suggests that the concept of the laws of nature developed by the new science - as exception less regularities-transferred to nature's regularity the "strong" character that Late Scholasticism attributed to finality and that the decline of the Late Scholastic view of finality played as an important concomitant factor permitting the transformation of the concept of laws of nature.

\footnotetext{
S. Manzo $(\bowtie)$

Universidad Nacional de La Plata, IdHICS - CONICET, La Plata, Argentina

e-mail: manzosa@yahoo.com.ar
} 


\subsection{Introduction}

Western reflection upon monsters originated in ancient times, maintained its relevance throughout the Middle Ages, and flourished in the sixteenth and the seventeenth centuries. The Aristotelian "scientific" and "naturalist" teratological tradition was integral to the heyday of literature about monsters in the Renaissance and early modern periods. It dealt with monsters as natural events to be explained by natural philosophy or physics. ${ }^{1}$ However, scarce scholarly attention has been given to the treatment of monsters provided by Late Scholastic textbooks, which were the main vehicles of the Aristotelian doctrines at that time. ${ }^{2}$ As is well known, Late Scholasticism was an eclectic and widespread manifestation of Aristotelianism that dominated university education particularly in the late sixteenth and seventeenth centuries, acting as the backdrop against which some developments of the new science and philosophy by central figures like Descartes, Galileo, Hobbes, Spinoza, Leibniz, Newton, and others took place. ${ }^{3}$

While departing from the Aristotelian framework, Late Scholastic treatments of monsters also made use of a wide range of ancient, medieval, and Renaissance sources such as Themistius, Simplicius, Pliny, Plutarch, Cicero, Galen, Augustine, Albertus Magnus, Aquinas, Averroes, Johann Boehme, Marsilio Ficino, Ambroise Paré, and Martin Weinrich, among others. They were typically not reduced to the Aristotelian framework, but varied and altered it, introducing further elements, different emphases, and new notions. As a result, this literature reassessed, modified, and systematized some of the concepts around which monsters were discussed at the time and continued to be discussed for the next two centuries: the ends and the fallibility of nature; the contrast between supernatural, contranatural, and preternatural; the notions of impeded and impeding natures; the relation between particular and universal natures; and the role of chance and divine providence. However, though sharing this common background, Late Scholastic claims about monsters did not constitute a completely homogeneous body of knowledge: they evolved across several subtly different veins and differed in emphases.

The aim of this paper is to reconstruct the main theses about monsters in some Protestant and Catholic Late Scholastic textbooks, by focusing on the question as to how their accounts conceived nature's regularity and teleology. While previous studies had noted the ways in which nature's regularity and teleology were thought in the late sixteenth century, this paper points out that both notions were strongly intertwined in the Late Scholastic view of nature in general and of teratology in particular. Hence, teratology constitutes a fecund case study to analyze how the laws and the ends of nature were thought at the time. By exploring this scarcely studied topic in these influential texts, this study seeks, on the one hand, to contribute to our knowledge of Late Scholastic views on monsters and, by these means, to

\footnotetext{
${ }^{1}$ Céard (1996); Lorraine Daston and Katherine Park (1998).

${ }^{2}$ Exceptions can be found in Des Chene (1996, 21-22, 203-210) and Guidi (2012).

${ }^{3}$ Reif $(1964,1969)$ 17-32 and Schmitt (1983a).
} 
help us understand more fully sixteenth- and seventeenth-century teratology. On the other hand, this study sheds some light on the history of the early modern concept(s) of laws of nature, in analyzing the way in which Late Scholasticism conceived exceptions to nature's regularity within a teleological framework. A better understanding of Late Scholastic views on nature's regularity and teleology will contribute (in further studies) to the more accurate delineation of the innovations introduced by modern concepts of the laws of nature which comprised, on the one hand, different ideas of regularity and, on the other, challenges to teleology.

This paper will show that Late Scholastic manuals endorsed a naturalistic approach that, in contrast to the naturalistic explanations usually offered by the new science, gave a prominent place to finality as a necessary component of the casual account of monsters. Certainly, most manuals left aside the portentous account of monsters like the newer teratology did. However, unlike the latter, the rejection of the portentous interpretation of monsters did not led Late Scholastic authors to exclude goals from their explanations. This general point does not impede to remark some differences among the Late Scholastic corpus. Some authors, like Toledo, Pereira, and Burgersdijck, were closer to the views emerging in the Scientific Revolution insofar as they conceived nature as relatively more autonomous from God's control and gave a relevant place to efficient secondary causation. To a certain extent, the role they conceded to secondary efficient causation collided with the strong teleological pattern of nature characteristic of the Late Scholastic overall view of nature. Precisely tensions inside the Late Scholastic account at least in part motivated the abandonment of teleology, or at least of the "strong" finality endorsed by it. In this connection, I will suggest that the concept of the laws of nature - as exceptionless regularities-developed by the new science transferred to nature's regularity the "strong" character formerly attributed to finality. By this move, the laws of nature were transformed from "weak" to "strong" regularities.

This paper is organized into seven sections. After the introductory first section, in the second section I provide a brief justification and an account of the contexts and authors of the textbooks selected for this study. In the following section, I offer a short description of the broad metaphysical views concerning regularity and teleology with respect to monsters assumed by this literature. There, I introduce into the definitions of weak regularity and strong teleology, which I will use in my interpretation. Section four discusses the characterization of monsters as nature's mistakes and preternatural events admitted by what I call "weak" laws of nature. In the fifth section, I show the different strategies developed to make the existence of monsters compatible with what I consider to be a notion of nature's "strong" finality, by means of conceptual tools such as particular and universal natures, impeded and impending natures, and different sorts of ends. The next section deals with the views of our authors about the interpretation of monsters as portents. The last section addresses the question of the accidental character of monsters and their relation to chance and God's providence. In the conclusion, I draw some general remarks about how nature's regularity and teleology were conceived by the textbooks and suggest in rough terms how they are related to more modern views. 


\subsection{The Textbooks: Authors and Contexts}

This study will explore the natural philosophy manuals widely read in arts and medicine faculties of Post-Reformation universities in which the treatment of monsters is more deeply developed. ${ }^{4}$ The influence of Catholic commentaries was pervasive in Protestant textbook authors, and they shared many views. ${ }^{5}$ Not surprisingly, the treatment of monsters in Catholic manuals here selected (mainly those by Toledo and the Coimbrans) was read attentively and much of the time followed by Protestant authors. This broad agreement in large part stemmed from the fact that the notions involved in their discussions on teratology did not touch any point linked to the Post-Reformation theological controversies.

As for the Catholic representatives, our survey will consider, on the one hand, textbooks by Jesuit authors, which were primarily intended for use at the colleges and universities linked to the Society of Jesus. The general orientation of the Society was a modified Thomistic Aristotelianism, which exerted great influence across European Catholic and Protestant universities. ${ }^{6}$ The earliest Jesuit texts of our selection were composed by Francisco Toledo (1532-1596) and Benito Pereira (15351610), the most influential professors at the early Collegio Romano. Before becoming a Jesuit, Toledo studied at Salamanca under the Spanish Dominican Domingo de Soto (1494-1560). Besides the Thomist penchant, his commentary on Aristotle's Physics (1573) - which combines summaries of Aristotle's texts with quaestiones - also took into consideration the ancient commentaries and the Arab tradition. Pereira published in 1576 De communibus omnium rerum naturalium principiis et affectionibus, a textbook organized in 15 books which covers systematically Aristotle's natural philosophy. ${ }^{7} \mathrm{He}$ had studied at the Collegio Romano and became professor there in 1556. His exposition favored the Thomist interpretation over the Greek and Latin traditions but did not exclude nominalist and Scotist views. In addition, he was more sympathetic to Averroism than other Jesuits from the Collegio Romano. In his textbook Pereira is intending to give a naturalistic account of the "principles" of nature, which are thought to be the real causes of things. ${ }^{8}$

Probably, the most influential Jesuit textbooks were those composed by the Portuguese College of Arts at Coimbra, which commented on several of Aristotle's works and produced a philosophical course encompassing logic, physics, biology, and ethics. These manuals became the reference works of Late Scholasticism during the seventeenth and the eighteenth centuries not only in Europe but also in South

\footnotetext{
${ }^{4}$ It goes without saying that it is far beyond the scope of this paper to exhaust the huge amount of natural philosophy textbooks circulating at that time. It is hoped that the textbooks discussed here can be considered to be representative of the whole.

${ }^{5}$ Reif (1964) ch. 1; Schmitt (1983a) 149.

${ }^{6}$ Ariew (2003) 162-169.

${ }^{7}$ Most bibliographies have established that De communibus came out first in 1562, but recently Blum (2006) 280, 295 n. 3, has challenged this date by arguing that it first appeared in 1576.

${ }^{8}$ On Pereira's relation to Averroism, see Blum (2006) 280-284. See Wallace (2000) 228-229; Blum (2006) passim; Lohr (2000) 606-609.
} 
America and China. Compared to their colleagues from the Collegio Romano, the Coimbrans were more conservative. ${ }^{9}$ The commentary on Physics (1592) was written by Manuel de Góis (1543-97), who studied at the Jesuit College of Montego. The most important issues of each chapter are subsequently discussed in long series of quaestiones which offer a detailed and insightful account of precedent and contemporary interpretations, making ample use of a very wide range of ancient, medieval, and contemporary sources. ${ }^{10}$

The commentary on the Physics (1605) by the Spanish Jesuit Antonio Rubio (1548-1615) is very much indebted to the Coimbran and Toledo's commentaries. Rubio, who had studied at Alcalá and entered the Society in 1659, taught from 1576 to 1599 in the Jesuit Province of Nueva España (Mexico) and produced commentaries on several of Aristotle's works, later published in Europe, and read in several universities. ${ }^{11}$ Another source followed by Rubio in his treatment of monsters is the Disputationes Metaphysicae (1597) of the Jesuit Francisco Suárez (1548-1617), a widely read commentary on Aristotle's Metaphysics, which incidentally dealt with some questions related to monsters. ${ }^{12}$

On the other hand, a different Catholic approach is to be found in Eustachius a Sancto Paulo (1573-1640), who had studied at the Sorbonne and became professor there, before entering the Cistercian congregation of the Feuillants. Eustachius was an influential figure of the French Catholic revival, whom Descartes held in high esteem. As other authors educated at Paris at the time, Eustachius was more inclined toward Scotist positions. His work Summa philosophiae quatripartita de rebus dialecticis, moralibus, physicis, et metaphysicis (1609) was widely read both in Catholic and Protestant circles. It is a systematic exposition covering the whole philosophy and excluding mathematics. Unlike the Jesuit textbooks above mentioned, this manual contains few discussions of precedent contemporary interpretations. $^{13}$

As for the Protestant textbooks, this essay will deal with works by Bartholomeus Keckermann (1571-1609), Johannes Magirus (d. 1596), Franco Burgersdijck (1590-1635), and John Case (1540-1600). Both Keckermann and Magirus were educated at Protestant universities, typically inspired by the Philippist educational program initiated at the University of Wittenberg. While the first Protestant textbooks were composed at Wittenberg by an early supporter of Luther's revolt, Johannes Velcurio (1490-1534), it was Philipp Melanchthon (1497-1560) who became the leading intellectual figure of Lutheran reformed universities. ${ }^{14}$ Keckermann belonged to a later Protestant generation and was one of the most read textbook authors across Europe. Born to a Danzig Calvinist family, in 1590 he

\footnotetext{
${ }^{9}$ Wallace (2000) 229.

${ }^{10}$ de Carvalho (2011) 1-13.

${ }^{11}$ Osorio Romero (1988) 9-34.

${ }^{12}$ On Suarez, see Lohr (2000) 611-617.

${ }^{13}$ Ariew (2003) 164-169.

${ }^{14}$ Kusukawa (2008) 111. On the fate of Velcurio's works and his influence on the Lutheran world, see ead. (1995) 109-112.
} 
entered the University of Wittenberg, where he was introduced to the Aristotelian philosophy through the interpretation and method of Paduan Aristotelianism as developed by Jacopo Zabarella (1533-89). When Calvinist students were expelled from Saxon universities, he moved to Heidelberg. As professor at Heidelberg and Danzig, Keckermann became a convinced Aristotelian very much engaged with a pedagogical reform. He developed a new method of exposition of Aristotle's thesis, which was applied to the whole range of disciplines in a 3-year course. His treatment of natural philosophical issues appears in Systema physicum (1610). ${ }^{15}$

A similar mix of Zabarellian and Protestant education was received by Johannes Magirus, who in 1591 became professor of natural philosophy, after having studied at Padua under Zabarella. Later, he received a doctoral degree in medicine at the Philippist University of Marburg (1585). His natural philosophical work, Physiologia peripatetica, posthumously published in 1597, was read not only in Marburg but also in Cambridge and Harvard. It is a compact exposition which roughly follows the usual order of topics, like Keckermann's. Between 1605, when the University of Marburg was converted to Calvinism, and 1624, when it came back to Lutheran orthodoxy, Magirus's textbooks took part in the conciliatory attitude toward philosophical and theological issues, which characterized this institution under the influence of Rudolph Goclenius (1547-1628). ${ }^{16}$

Another influential Protestant figure, particularly in Northern Europe, was the Dutch Franco Burgersdijck (or Burgersdijk), who studied at the University of Leiden and the Protestant Academy of Saumur in France. He was appointed professor in Leiden to fill one of the vacancies produced by the anti-Arminian purge promoted by the Synod of Dort. As professor, he transformed the teaching of philosophy into a discipline independent from theology and philology. His textbooks on natural philosophy, Idea philosophiae naturalis (1622) and Collegium physicum (1632), were widely used in Protestant universities until the end of the seventeenth century. The first one is an epitome of Aristotle's Physics which selects definitions and controversies from expositions by Zabarella, Toledo, Pereira, and the Coimbrans, with the aim of simplifying the learning of physics. The second one is a longer and more original exposition organized in disputationes on several selected topics. ${ }^{17}$

What Burgersdijck represented for Dutch universities, John Case represented for the British scene. Case took his BA (1567), MA (1572), and MD (1589) from Saint John's College (Oxford) and was a fellow there between 1572 and 1574. Though he had been accused of being a secret Catholic, more recent studies suggest that is not possible to align him with a particular religion. Moreover, Case was equally attached both to loyal Anglican theologians and to recusants. ${ }^{18}$ This paper, however, will show that Case endorsed a staunch providentialism, akin to that found in English

\footnotetext{
${ }^{15}$ Freedmann (1997); Hotson (2002) 43-47 and (2007) 136-156; Mack (2011) 186-92.

${ }^{16}$ Rogers (1988) 10 and Flower (1988) 23; Wallace (2000) 230; Kusukawa (2008) 117; Maclean (2012) 275 n. 56.

${ }^{17}$ Rüstow (1973) 14-33; Krop (2011) 60-62.

${ }^{18}$ Schmitt (1983b) 114-116 and n. 41. See Copenhaver and Schmitt (1992) 124, and in general 121-126.
} 
Protestantism, and, accordingly, a commitment to the interpretation of monsters as portents -exceptional as compared to the rest of authors of our corpus. Educated in Humanism and Scholasticism, Case developed an open-minded and eclectic Aristotelianism. He composed several pedagogical works on several matters. Two of his works, Ancilla philosophiae and Lapis philosophicus - both printed in Oxford in 1599 - were meant to provide expositions of Aristotle's Physics: the first one as a very brief introduction for beginners and the second one as a more original and detailed exposition, including discussions of commentaries by Toledo, Pereira, and the Coimbrans. ${ }^{19}$

\subsection{The Metaphysical Assumptions: Weak Regularity and Strong Finality}

The notions of regularity and teleology assumed by the selected manuals in their thought on monsters can be traced back to doctrines originally introduced in Aristotle's loci classici on the issue. The classification of biological heredity presented in Generation of Animals places monsters in the class of offspring who do not resemble their parents. In monstrous births, the natural process does not follow its regular course. Aristotle points out specific circumstances to explain why monsters are born: the motions proceeding from the male are not dominant; the space available in the uterus is insufficient; the material contributed by the mother is deficient; etc. ${ }^{20}$ In addition, he establishes that monsters are exceptional beings $\pi \alpha \rho \alpha$

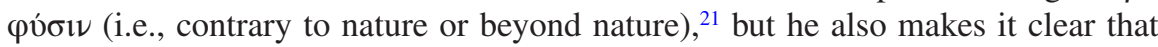
they do not go against all kinds of nature, but only against a certain kind of nature (i.e., against the nature of the specific form of the parents). Moreover, he claims that even that which is contrary to nature is in a certain sense in accordance with nature, since monsters arise whenever the "formal" cause fails to dominate the "material" cause. $^{22}$ This situation can take place only among those things which occur for the most part and which may occur contrary to that, but not in those things which occur always and by necessity. ${ }^{23}$

This last point is essential to understand the medieval and Late Scholastic approaches. Like Aquinas, the textbooks conceive that sublunary nature admits exceptions to its regular course, since its regularity consists in what happens always or for the most part (aut semper aut plerunque). ${ }^{24}$ This way of characterizing the regular course of nature - which refers to nature as process - is what for brevity's

\footnotetext{
${ }^{19}$ Schmitt (1983b) 74-76; 152-153; 156-159.

${ }^{20}$ Aristotle (2000) IV, 3-4, 769 b10-770b27.

${ }^{21} \mathrm{As}$ for the different interpretations and translations received by the expression $\pi \alpha \rho \alpha \grave{~} \varphi v ́ \sigma ı \nu$, see p. 10 of the pdf manuscript (there is no page number in proof).

${ }^{22}$ Aristotle (2000) IV, 4, 770b15-17. See Rossi (2011) 268.

${ }^{23}$ Aristotle (2000) IV 4, 770b10-18.

${ }^{24}$ Daston and Park (1998) 120-122. See Aquinas (1975), lib. 3, ch. 99, n. 9.
} 
sake I will call the "weak" sense of regularity: a view according to which the regular course of nature can be interrupted and admits exceptions. ${ }^{25}$

On the other hand, in Physics Aristotle refers to monsters when dealing with final causes and defines them as mistakes of nature in the attainment of its end. ${ }^{26}$ To Aristotle the issue of teleology was directly related to nature's regularity: what occurs always or for the most part must occur on account of some end. If the natural world were disordered, every natural occurrence would be a consequence of chance. Hence, acts which fall short of their ends look like anomalies to the omnipresent finality reflected by the weak regularity of nature's order: they appear to be counterexamples which require ad hoc explanation. ${ }^{27}$

Unlike the Aristotelian biological description of monstrosity in Generation of Animals, which did not challenge Christian tenets, the definition provided in Physics did entail a conflict with them. From the Physics definition - which refers to nature as producer $--^{28}$ there follows a notion of nature as fallible, which not only puts at risk the conviction that nature always, not just for the most part, acts on account of an end. This notion also goes against the figure of the Christian God governing and controlling nature, which the textbook authors - regardless of their religious affiliation - aimed at defending. What for brevity's sake I will call "strong" finality is the standard view that everything in nature occurs on account of an end, so that every natural change is a directed change. ${ }^{29}$

This does not entail, however, that regular ends in nature are by themselves inescapable. In fact, monsters are precisely the sort of events showing that sometimes regular and primary ends are not attained. In fact, as we shall see, textbook authors explained monstrous generation by claiming that since the regular end of generation is unattained, another end replaced it. The sense in which finality can be qualified as strong refers, therefore, to the idea that, after all, nature always acts toward one (regular and frequent) end or another (irregular and rare) end. It comes as little surprise, then, that all the textbook treatments dwell on the question "whether nature intends monsters." 30

\footnotetext{
${ }^{25}$ Daston and Park (1998) 14, 110, had referred to this kind of regularity in terms of "habits" or "customs" of nature. See also Maclean (2000) 233-235; id. (2007) 268-271; id. (2008) 33-36. On customs and laws of nature, see also Steinle (2001) 77-98; Daston (2004).

${ }^{26}$ Aristotle (1998) II, 8, 199b4.

${ }^{27}$ On the idea of monsters as counterexamples, see Des Chene (1996) 172.

${ }^{28}$ The hermeneutical distinction between nature as process and nature as producer is inspired by Maclean (2007) 247.

${ }^{29}$ See Des Chene (1996) ch. 6.

${ }^{30}$ This concern with teleology was commonplace in Late Renaissance literature on monsters inspired in Aristotle. See, for instance, Hanafi (2000) 27-33.
} 


\subsection{Nature's Mistakes, the Preternatural, and "Weak" Laws of Nature}

The image of monsters as mistakes of nature, along with the assumption that nature is fallible and deviates from its ordinary course, made its way throughout the Middle Ages at least until the eighteenth century. ${ }^{31}$ The textbooks furthered this note by associating the existence of monsters with nature's liability to error. Pereira puts this idea very clearly: "it is necessary that what is fallible (defectibile) sometimes fails; hence exist the reason and the origin of monsters." 32 In other words, as Rubio says, something is called "monster" for being a "defect." 33 This association became an essential mark of monstrosity in the standard definition of monsters (apparently of Jesuit origin) across Catholic and Protestant textbooks: a monster is a natural effect that degenerates from the correct and habitual disposition which is consonant with the species ("naturalis effectus a recta et solita secundum speciem dispositione degenerans"). ${ }^{34}$ Along the same line, Magirus defines monsters as "deviations and flaws" of the nature of an individual that deviates from its end through the intervention of an impediment. ${ }^{35}$

In addition, in Protestant textbooks are to be found definitions which describe monsters as bodies whose defective arrangement indicate some kind of irregularity in their figure. Thus, Velcurio writes that monsters are "natural bodies that do not have their members correctly set, nor do they have the usual proportion between their parts." 36 Similarly, Keckermann defines them as "living natural bodies" that have some peculiar defect, a certain flaw (peccatum) or an immense deviation (aberratio enormis) from nature.$^{37}$ In the same vein, Burgersdijck says that a monster is a "living body much degenerating from the lawful and natural conformation of its members." As we shall later, these Protestant definitions do not entail that the

\footnotetext{
${ }^{31}$ Daston and Park (1998) 201-214; Bates (2005a) 142; Guidi (2012) 61-108; Davies (2013) 49-75.

${ }^{32}$ Pereira (1585) lib. 9, ca. x, 528.

${ }^{33}$ Rubio (1629) lib. 2, ca. ix, qu. unica, 284.

${ }^{34}$ The definition was apparently coined by Toledo (1580) lib. 2, ca. ix, qu. xiii, fol. $76^{\mathrm{r}}$. It appears later - sometimes with slight variations- in Conimbricenses (1594) lib. 2, ca. ix, qu. v, art. I, 339; Burgersdijck (1645) dis. III, thesis 13, 17; Eustachius a Sancto Paulo (1647) Pars Physica, trac. ii, qu. ii, 147; Rubio (1629) lib. 2, ca, ix, qu. unica, 283; Keckermann (1623) lib. 5, ca. iii, 595; Case (1600) lib. 2, ca. viii, 345. In some cases, the genus of the definition is not "natural effect" but "natural birth" (partus naturalis) or "natural living being" (vivens naturale). See also Chauvin (1692) sub voce. Some authors held more or less explicitly that monsters occur only in living beings (plants and animals) as contrasted with unanimated beings. See Pereira (1585) lib. 9, ca. x, 529.

${ }^{35}$ Magirus (1646) lib. 1, ca. iii, 55.

${ }^{36}$ Velcurio (1558) lib. I, ca. x, 39: "corpora naturalia, quae non habent iustum situm membrorum, neque consuetam Naturae proportionem partium." The same definition is provided by Goclenius (1613) 708.

${ }^{37}$ Keckermann (1623) lib. 5, ca. iii, 594.
} 
irregularity visible in the bodies of the offspring points out an irregularity of their formal causes, since what is defective is only the individual body. ${ }^{38}$

Rather than as pure and simple effects, monsters were thought of as defects for which nature is solely responsible. From a Christian perspective, it was impossible to claim that God is the cause of a defect. As the Coimbran explanation of the standard definition argues, monsters are not supernatural events produced by God and should not be confused with divine miracles. Even if occasionally the effects produced by man that defy the rules of a particular art are called "monsters," this term is only applied to them in analogy with nature. In sum, the sole cause of monsters is nature, and, accordingly, they are said to be natural. ${ }^{39}$ Nonetheless, insofar as monsters are not usual but rare events, they are more specifically conceived as preternatural effects. This reading draws on a passage from Generation of Animals, where

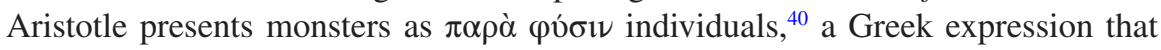
can be translated as "contrary to nature" (contra naturam) or as "beyond nature" (praeter naturam). ${ }^{41}$

Certainly, Christian readers of Aristotle were reluctant to accept that generation could be contrary to nature, since nature was the work of God and nothing could operate against his power and will. The thirteenth-century first Latin translation of Generation of Animals by William of Moerbecke renders $\pi \alpha \rho \grave{\alpha} \varphi v ́ \sigma ı$ as praeter naturam. ${ }^{42}$ This tendency remained in later Renaissance translators, ${ }^{43}$ like Theodore Gaza, responsible for the most widespread Latin version of Aristotle's treatises in natural history at that time, probably consulted by the textbook authors. ${ }^{44}$ Against this background, John Case, for instance, characterizes monsters as errors qua effects. But, at the same time, he emphasizes the fact that in monsters the error lies in the particular nature qua cause. ${ }^{45}$ They constitute "imperfect acts," resulting from

\footnotetext{
${ }^{38}$ Burgersdijck (1643) dis. XXIV, a. 2, i., 261; ib., q. xi, 249.

${ }^{39}$ Conimbricenses (1594) lib. 2, ca. ix, qu. v, art. ii, 339. The Coimbran commentary draws on Toledo's explanation of the standard definition, Toledo (1580) lib. 2, ca. ix, qu. xiii, fol. $76^{\mathrm{r}}$.

${ }^{40}$ Aristotle (2000) IV, 4, 770b10-18.

${ }^{41}$ Maclean (2007) 252-256 notes that expressions like "praeter naturam," "contra naturam," and "secundum naturam" were intended in different ways in Renaissance medical discourse. The same goes, I would suggest, for the literature explored in this paper.

${ }^{42}$ Aristotle (2000) IV, 4, 770b10-17; Aristoteles Latinus (1966) 135.

${ }^{43}$ As far as I know the only exception appears in Michael Scotus' thirteenth-century Latin translation of the Arabic Kitāb al-Hayawān ("Book of Animals") which contains parts of De generatione animalium. Peck's English translation of 778a 5-9 says: "things occurring contrary to Nature

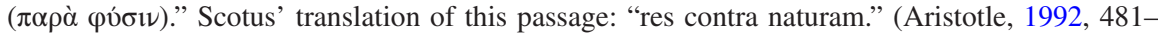
483, my italics).

${ }^{44}$ Editio princeps: Aristotle (1476). Reprinted in the monumental Giunta edition, Aristotelis Opera cum Averrois commentariis (Aristotle, 1560) IV. Gaza's reading of De generatione animalium, IV, 4, 770b10-18 says: "monstrosum est enim res praeter naturam. Sed praeter eam, quae magna ex parte sit, nam praeter eam, quae semper et necesario est, nihil fit.", Aristotelis Stagiritae libri omnes ad animalium cognitionem attinentes, cum Averrois Cordubensis variis in eosdem (Aristotle, 1962) VI, fol. 243r. On the Latin translations of Aristotle's biological treatises and the high impact of Gaza's translation, see Beullens and Gotthelf (2007) and Perfetti (2000) 12-28.

${ }^{45}$ On the notion of particular nature, see p. 13 of the pdf manuscript proof. There are no page numbers in the proof.
} 
the "preternatural potency" of matter. In turn, they are distinguished from "violent acts," that is, acts "against nature," which are caused by an external cause which deprives the nature of the thing of its own potency and leads it to corruption. ${ }^{46}$ As it can be seen here and in other authors like Pereira, etc., matter's recalcitrance was often alleged as one cause, often the principal cause, of the generation of monsters. This very idea comes back to Aristotle's view that monsters arise whenever the "formal" cause fails to dominate the "material" cause.

How are these preternatural events related to nature's taxonomy? Do they constitute species on their own? Or are they just individual cases? Textbook authors maintain that monsters are exceptional cases within a species, but do not constitute species by themselves. Each species has a disposition and a conformation of its members. When individuals are born that do not follow this rule, the result is a monster which can be associated with a certain species. In monstrosities, the degeneration of the species is only partial, since an offspring resembles its parents to some degree: an olive is not generated from a man, neither is an animal generated from a plant. ${ }^{47}$ Monstrosities are derivatives upon a preexistent order against which they can be recognized and measured as aberrations. Otherwise, aberrations would not be possible at all, since there would be no given standard to which to be compared. ${ }^{48}$ Hence, since not every "irregularity" constitutes a monstrosity, it is extremely important to observe carefully how far individuals deviate from the preexisting order. The treatment by Keckermann is particularly insightful on this point. His exposition on monsters is included in book V, devoted to living bodies. After establishing that living bodies can be regular or irregular, he claims that irregularity is a matter of degrees, depending on how far a body moves away from "nature's order and perfection." While the "less irregular" remissions or intensions of nature (remissio et intensio) are not monstrous - as in the cases of women, giants, and pygmies - the "more irregular" and greater deviations (aberrationes) are monstrous, such as a two-headed animal. ${ }^{49}$

Given their endorsement to the idea of weak regularity, though some textbooks talk about the regularity and order of nature in terms of "laws" or "rules," they do not regard them as exception less. ${ }^{50}$ The Coimbran commentary explains that a monster is "a deviation from the order and law that an end prescribes to the operations of nature and in accordance to which nature itself operates" ("deflexio aliqua $\mathrm{ab}$ ordine ac lege, quam naturae operibus praescribit finis, propter quem natura ipsa operatur"). In other words, it is a defect which digresses "from a law of nature"

\footnotetext{
${ }^{46}$ Case (1600b) ca. v, 34.

${ }^{47}$ Toledo (1580) lib. 2, ca. ix, qu. xiii, fol. $76^{\mathrm{r}}$.

${ }^{48}$ On the normative character of regularity in Late Scholastics philosophy, see Des Chene (1996) $21-22$.

${ }^{49}$ Keckermann (1623) lib. 5, ca. iii, 595-600. On the status of giants and dwarfs in this regard, see Conimbricenses (1594) lib 2, ca. ix, qu. v, art. ii, 339-340; Burgersdijck (1643) dis. XXV, 265; Rubio (1629) lib. 2, ca. ix, qu. unica, 283; Case (1600a) lib. 2, ca. viii, 345.

${ }^{50}$ The same can be found in medical texts of the sixteenth century. See Bates (2005b) 14-15.

${ }^{51}$ Conimbricenses (1594) lib. 2, ca. ix, qu. v, art. ii, 339; 342.
} 
is "beyond its common course or rule [regula]." ${ }^{52}$ Rubio makes the same point. A natural effect is called a monster insofar as it fails to achieve the perfection that would have occurred in accordance with the usual laws (consuetas leges) that nature keeps in its actions. In his opinion, giants and pygmies are not monsters, because they are not generated "beyond the laws of nature, but in accordance with them," being effects of the peculiar physical properties - extreme fecundity and sterility, respectively - of the land where they were born. ${ }^{53}$ When monsters are born, Case writes, we become astonished because second causes invert the usual order and shake the laws (legibusque concussis). ${ }^{54}$

Within this worldview, preternatural fallibility is possible insofar as nature has purposes: only what has a purpose can fail in the accomplishment of it. A fortiori, the fallibility derived from the purposive character of nature, entails that there is no guarantee that the regular course of nature is always maintained. The weak regularity of nature is therefore possible only if nature's fallibility and hence its purposiveness are assumed. This entails, in addition, that, being fragile, the laws of nature lack necessity and permit exceptions. Indeed, when a preternatural deviation from the ordinary course of nature occurs, the law is not violated strictu sensu, since the deviation is a possibility envisaged by the very notion of law. Rather than violations, monstrous deviations are exceptions: irregular outcomes perfectly admissible in the course of nature.

\section{5 "Strong" Finality and Diversity of Ends}

The textbooks devised different ways to argue that, albeit errors, monsters are compatible with nature's omnipresent teleology, so nature maintains its purposive character. The authors deployed a number of conceptual tools to help deal with this dilemma. They included the sheer number of teleologies in nature, a distinction between universal and particular natures, and a distinction between "impeding" and "impeded" natures (also called impeding and impeded causes).

As for the diversity of ends, first it should be noted that Late Scholasticism thought of the immediate ends of nature as changes in two different senses. On the one hand, an end is an intended state, the terminus ad quem of one operation, the attainment of which coincides with the cessation of change. On the other hand, an end is the beneficiary of the operation, that is, the thing for whose benefit the change occurs, which may or may not be the subject of the intended state. If someone takes a pill to restore her health, the condition to be achieved is the health, and the beneficiary is the person. Both are ends of the same change in different respects. As we shall see, the textbooks agree that monsters are ends, since they are termini ad

\footnotetext{
${ }^{52}$ Keckermann (1623) lib. 1, ca. i, 4.

${ }^{53}$ Rubio (1629) lib. 2, ca. ix, qu. unica, 284; ib., ca. viii, qu. unica, 281 he talks of "regulae consuetae."

${ }^{54}$ Case (1600a) lib. 2, ca, viii, 346.
} 
quem of some generative processes but diverge on determining what or who the beneficiaries of such generation are. In so doing they appeal to different kinds of ends which become unified by subsumption: individual ends, collective ends, and cosmic ends are subsumed to one another, and all subsumed to the ultimate end, God. ${ }^{55}$ Behind this hierarchy of ends, one way or another the time-honored maxim keeps valid: nature always acts toward an end. Such a maxim was entangled with the conviction that a beneficiary always corresponds with the intended states of natural changes. Both claims were at the core of strong finality.

Besides assuming several senses and kinds of ends, the manuals appealed to the distinction between causa universalis or natura universalis, which had several senses depending on the context. ${ }^{56}$ Usually the plural form causae/naturae universales referred to the celestial virtues (heavenly substances) in contrast with causae/naturae particulares, which embraced all sublunary agents submitted to them. However, the singular form causa/natura universalis exceptionally meant God as the first cause, the universe, or the species of sublunary particular agents generally in biological and medical texts. ${ }^{57}$ As we shall see, in the causal explanation of monsters by "universal causes," the manuals usually intended the heavens and, by "particular causes," the parents or the species, of which monsters are effects.

Another conceptual distinction was related to the idea that in monstrous generation the regular end of generation is obstructed by some kind of impediment. ${ }^{58}$ This very idea was derived from Aristotle's view that in sublunary nature things occur regularly "if nothing impedes it." 59 Accordingly, to explain monsters in terms of impediments, Late Scholastic authors called "impeding" nature (or cause) the nature that impedes the attainment of the regular end (for instance, small uterus, excess of matter, etc.) and "impeded" nature (or cause) the agent of the generation (usually the parents) which is obstructed by such impediment in the attainment of its purpose.

All such concepts played a crucial role in explaining the teleological sense of monsters. All of them - by implication at least- would agree that ultimately all the ends pursued in monstrous generation are subsumed to God's ends. Particularly in Magirus is found an emphasis on the supremacy of God's ends in monstrous births. He maintains that nature does not have the intention of producing "new and unusual forms," which is to say something alien and distorted. The end of everything in

\footnotetext{
${ }^{55}$ Des Chene (1996) 171-177. See, for instance, the classification of ends offered by Rubio (1629) lib. 2, ca. viii, qu. unica, 280.

${ }^{56}$ Recent studies show that the origin of this distinction dates back to Avicenna and was adopted in several ways by Roger Bacon, Albertus Magnus, Thomas Aquinas, etc., to give account of the generation of monsters, the rejection of void, etc. See Weill-Parot (2012) 15-38, Panti (2013) 101-130, and Manzo (2013).

${ }^{57}$ See Des Chene (1996) 143, n. 30; Mac Lean (2007) 236-247.

${ }^{58}$ This approach has, of course, medieval antecedents. See, for instance, Aquinas (1975) lib. 3, ca. 154, n. 11.

${ }^{59}$ Aristotle (1998) II 8, 199a9-11, b18, 25-26. The sense of this formula is very similar with the sense of $\pi \alpha \rho \alpha \grave{~} \varphi v ́ \sigma ı v$ with respect to monstrosities in Generation of Animals, II 6, 745b9-11

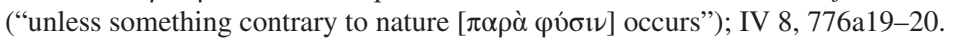


nature is God's glory, which is the highest and universal end, for the sake of which everything is done. ${ }^{60}$ Like him, Eustachius claims that God seeks his glory, when he concurs with the cause that impedes the attainment of the regular end of generation. He argues that while monsters are beyond the intention of the impeded cause, they are not so with regard to the impeding cause, let alone regarding the intention of God, the supreme cause which commands the errors of nature for his greater glory. ${ }^{61}$ Behind the claim that defective offspring involve God's glory is the principle of plenitude, a world including the whole variety of regular and irregular beings can only be the work of the highest almighty creator.

Nonetheless, some manuals claim explicitly that when monsters are born, the world (understood as individuals, species, or the whole universe) is the beneficiary. ${ }^{62}$ Burgersdijck's strong naturalism goes along this line. He began by asking: since nature always acts toward an end, why should it not be so when it generates monsters? In ordinary generation, individuals tend to produce an effect like themselves aiming to preserve their species. In spite of this, when they are impeded in attaining that state, they intend by a secondary intention to produce an offspring completely resembling their form or soul, and as much as possible resembling their body or matter. ${ }^{63}$ Only the material aspect of the monstrous offspring is dissimilar to its progenitors. While its soul is like its parents' soul (formal cause), its body is not. Accordingly, when nature makes monsters, it "does not frustrate its entire end [...], but only a part of it." 64 Now, Burgersdijck seems to suggest that, say, a twoheaded horse, regardless of having a defective body, is still a horse because it has a horse's form. Hence, to a certain extent the species horse as a whole is benefited by this state pursued by the secondary intention, for its form is maintained.

Keckermann seems to follow the same line, in admitting that nature only in part fails to obtain its ends in monstrous generation. When nature strives for generating natural bodies, it searches for perfect bodies, and not for aberrations or defects. But monsters cannot be themselves the ends of generation, because they are imperfect creatures. That leads him to the conclusion that when monsters are generated, nature only tends to what is perfect in them, but not to what is defective. ${ }^{65}$

Similarly, Rubio appeals to secondary intentions to argue that monstrous generation does good to nature. When the primary intention of particular causes cannot be achieved, secondary intentions are sought. He opposes the opinion of Suárez, according to which although with respect to particular causes monsters are causal effects, with respect to universal causes - that is, the heavens- monsters are

\footnotetext{
${ }^{60}$ Magirus (1646) lib. 1, ca. iii, 50-51; 55. It follows Velcurio (1538) sine folio [G8r?].

${ }^{61}$ Eustachius (1647) trac. ii, dis. iii, qu. ii, 147.

${ }^{62}$ I follow the terminology of the textbooks in using the singular "nature" to design different things: individuals (like the parents, the impeding nature, the impeded nature, etc.), the species (man, horse, etc.), and the whole of nature (sometimes identified as "the world," "the universe," and even metonymically the "heavens" to which the entire nature is submitted).

${ }^{63}$ The resort to the concept of "secondary intention" has medieval antecedents, for instance, in Roger Bacon. See Panti (2013) 116-117.

${ }^{64}$ Burgersdijck (1643) dis. XXIV, a. 2, i, 264-266. Cf. dis. XXIV, q. x, 350-351.

${ }^{65}$ Keckermann (1623) lib.5, ca. iii, 595.
} 
intended per se. That is because, Rubio explains, while particular causes tend toward one certain goal and cannot tend per se toward contingent goals deviating from it, universal causes have a "larger extent and intention" ("maiorem ambitum, atque intentionem habentes"). On that basis, Rubio adds, Suárez's thesis claims that "what cannot be intended per se by particular causes is intended by universal causes, under which the virtue of particular causes is contained."'66 Against Suárez, Rubio holds that monsters are intended not only by the universal causes but also by the particular causes concurring in the generation, albeit they pursue them by secondary intention. In Rubio's account, we can observe that the individual primary end of the impeding cause (defective matter, small uterus, etc.), along with the collective ordinary end of parents, who strive for the preservation of the form of their species, are subsumed to the cosmic end pursued by the heavens which affects nature as whole. It is hard to imagine what might be the end pursued by impeding causes according to the Late Scholastics world image. Neither Rubio nor other commentators provide a positive answer to this question. We only find a negative answer: they do not seek a bad or defective effect by itself (in fact, no cause at all seeks for such effects).

Although Rubio does not explain what could be the benefit provided by monsters to nature as a whole, as we shall see, both he and Suárez argue that this cosmic end ultimately is warranted by God's "consequent will." God's consequent will is what he wants for creatures in relation to their capacity, while God's antecedent will is what he wants for creatures as far as he is concerned. ${ }^{67}$ Moreover, Suárez admits both alternatives that God wants to allow second causes to exert the motion that they are capable of (so they can achieve their individual or collective purposes) or wants to enhance the beauty of the universe through the diversity of creatures (in which case a cosmic end is desired) ${ }^{68}$ Pereira's stance approaches Suárez's last option by endorsing the principle of plenitude: God may have wanted monsters to exist so that the world would be complete by housing all kinds of beings, the necessary ones along with the contingent. ${ }^{69}$

On occasion, supporters of the position that the world is the beneficiary of monstrosities disputed their aesthetic value. Whereas some authors of the textbooks considered variety and plenitude as amounting to the world's beauty, others claimed that, being ugly deformities and defects, monsters by no means could contribute to increased beauty. A case in point is Toledo, who holds that the diversity of things yields to beauty only if such diversity consists of perfect effects. Besides, he provides

\footnotetext{
${ }^{66}$ Rubio (1629) lib. 2, ca. ix, qu. unica, 284. Cf. Suárez (1961) dis. XIX, sectio 12, n. 4. Rubio’s explanation of Suárez' rationale omits the main point made in this passage, which ultimately supports Suárez' claim concerning monsters: with respect to God, there are no casual effects in the universe.

${ }^{67}$ This widespread distinction and terminology dates back to John Damascene (676-749). See Damascene (1955) II c. 29- PG 94, 969; 160. A similar distinction with another terminology is attributed to John Chrysostom (347-407).
}

${ }^{68}$ Suárez (1961) dis. XXIII, Section 10, n. 11.

${ }^{69}$ Pereira (1585) lib. 9, ca. $x, 532$. 
a teleological explanation in terms of impeding and impeded causes. Although the proximate efficient cause does not intend the monster as such, the impeding cause and the universal causes do intend it, since they produce that from which a monster necessarily ensues. In addition, divine concurrence is needed to attain the whole operation. God concurs with the strong causes strongly and with the weak causes weakly so that the concurrence with some causes is impeded by the concurrence with the other causes "not from the side of the concurrence but from the side of the causes." ${ }^{70}$

A revealing illustrative example proposed by Toledo reflects the way in which the existence of monsters was interpreted as a type of internal conflict within nature, which reflects a conflict of ends. If an emperor has several subordinate kings who ask him for weapons which he gives them according to the condition of each one, then the weakest will be the one to fall in war. In this way, God, the supreme principal which sustains everything, gives operative virtues to all things and helps them to act in accordance with their own virtues. Of course, his goals play a role here, since God has given to all things a nature by which they are led unerringly to the God's goals, even without foreseeing them. If the ends of both weak and strong causes respond to the providential plan of the divine ruler, God's concurrence - accommodated as it is to their unequal powers - simply accomplishes his plan. In other words, this concurrence allowing the occurrence of defective effects "fully corresponds to God's providence." ${ }^{\prime 1}$ Such a view is also in line with Suárez's first alternative: God wants to benefit not the whole universe but individual agents by allowing them to exert their virtues.

Like Toledo's, the Coimbra commentary also offers a sophisticated explanation of the way in which impediments intervene in monstrous generation. However, it differs considerably in its account of the beneficiary of the change and in maintaining that they provide variety and increase the world's beauty. If, for example, a twoheaded horse is born, the impeded cause would be the parents, who try to engender a regular horse, whereas the impeding nature could be the excess of matter. Besides, the Coimbran commentary distinguishes three more components: the equine nature, the proximate ground (fundamentum proximum) of the deformity and the deformity itself or monstrosity. The impeded cause alone does not intend the monster: it is like a tradesman who desires to finish the work he is planning but is impeded from doing so. Neither is it intended by the impeding cause alone, since in the gestation of a monster there should necessarily be an impeded cause. That nature intends some effect means that it is inclined toward the realization of the effect that it produces. Since from the conjunction of the impeded and the impeding causes a monster is produced, then both causes as a whole (total cause) are directed toward the monstrosity as proximate ground of the deformity. Like Toledo, the Coimbrans appeal to God's concurrence to complete this explanation. God intends monsters, not immediately but through second causes (the impeded and the impeding causes)

\footnotetext{
${ }^{70}$ Toledo (1580) lib. 2, ca. iv, qu. xiii, fols. $76^{\mathrm{v}}-77^{\mathrm{r}}$.

${ }^{71}$ Ibid., qu. xiii, fols. $75^{\mathrm{v}}-77^{\mathrm{r}}$.
} 
insofar as he concurs with them. The world as a whole is benefited by this deviated effect, since it becomes ornamented by diversity. ${ }^{72}$

\subsection{For the Benefit of Human Souls: Monsters as Portents}

The rationale provided by Case to arguing for the teleological value of monsters challenges Coimbran's and Toledo's and introduces the portentous interpretation of monsters to maintain that human souls are the ultimate beneficiary. He wonders how the Coimbrans can "confidently defend" that nature intends monsters on the basis of the distinction between impeded and impeding causes. Considered in relation to God, Case argues, there are neither impeding nor impeded causes, both being simply instruments of his will. Besides, Case rejects what would be Toledo's stance, by affirming that if it is true that the impeded agent is not directed to a monstrous offspring, the same holds for the impeding cause. And that is because the end product is perfect and not defective with respect to the impeding cause, submitted as it is to God's command. ${ }^{73}$

If it is true that Case is not the only author of manuals claiming that natural agents are God's instruments, he shows nonetheless a remarkable difference of emphasis with respect to this point, by depicting nature as servant of God (ancilla dei) and by insisting on the fact that nature's actions are determined (certa, fixa) by divine providence. His analysis of monster teleology therefore shifts from nature to God. In Case's worldview, God rules and bends second causes in accordance with his free will and authority and uses "the truest causes" (verissimae causae) as instruments designed to different ends. Certainly, if these causes work in a way different from the common order of nature, it seems to us that a monster is produced with respect to the particular nature, which tends toward the regular offspring. But with respect to God, who foreknows the causes and commands that these things should happen, this effect is not a monster, nor a bad, evil, or imperfect thing, but a proper piece of his perfect plan. Through things produced beyond the common course and intention of nature, God aims at announcing future evils to exhort human souls to seek for salvation. God does not intend the production of monsters as errors of nature as such but uses them to send moral warnings, messages to exhort human beings to keep divine moral precepts. ${ }^{74}$ In other words, human beings are the beneficiaries of monstrous births, and monsters are signs which allow individuals to find out traces of the plan that God had designed for them.

The pioneering study by Céard maintained that conceptions of portent and wonders evolved together with naturalistic teratological traditions toward the naturalization of monsters. Current studies agree that natural philosophers and

\footnotetext{
${ }^{72}$ Conimbricenses (1594) lib. 2, ca. ix, qu. vi, art. i, 344-45 and art. ii, 346.

${ }^{73}$ Case (1600a) lib. 2, ca. viii, 347-48; 363.

${ }^{74}$ Case (1600a) lib. 2, ca. viii, 347-49. Ibid., 349: "potius clementer praemonere contendit de futuris malis, quam monstrum intendere." Cf. ibid., 346.
} 
physicians increasingly eschewed dealing with the moral and theological imports of monstrosities and regarded them simply as preternatural events requiring physical explanation, particularly by the 1670 s. However, portentous narratives of monsters persisted in Europe well into the seventeenth century, though in large part dissociated from naturalistic accounts. ${ }^{75}$ Except for Case's, most manuals of our survey broadly reflect this attitude: close to the Aristotelian naturalistic framework as they were, they either disregarded or explicitly rejected the interpretation of monsters as signs. Although in principle they did not point out a manifest contradiction between both lines, they intended to delimitate the realm properly belonging to the natural philosophical study of malformed offspring.

Such an attitude did not imply that theological matters should be completely excluded from naturalistic explanations. To the contrary, they were included as far as they were thought necessary to complete the account. A fortiori, the resulting causal narratives were developed so as not to collide with the essentials of theology. All the more so when the natural philosophical functions of God as first cause and designer of the world were enough to account for the origin of anomalous offspring, without taking in consideration the eventual moral and spiritual implications that monsters would involve. For Late Scholastics, this cooperation of second and first causes did not involve an unlawful intervention of theology into natural philosophy, but simply expressed the due harmony that they should maintain. ${ }^{76}$ Therefore, the omission of the portent interpretation from the naturalistic explanations did not entail that they resorted exclusively to secondary efficient and material causation and left aside, at the same time, final causes and divine providence. That is because Late Scholastics were convinced that the explanation of natural and preternatural events would be incomplete if finality were omitted.

Now, except for John Case, the finality alleged by our authors to complete their physical explanation did not attribute a portentous import to monstrosities. Concerning this particular point, we find the only remarkable though slight difference among Catholic and Protestant textbooks. ${ }^{77}$ In the case of Catholic textbooks, the lack of interest for monsters as portents becomes very explicit. Toledo's exposition clearly expresses the natural philosophical focus in detriment to the interpretation of monsters as signs. While he takes in consideration the Ciceronian etymology of the word monstrum - as signifying to "show" and to "predict" things - he quickly dismisses it, by arguing that it has scarcely anything to do with his aim of explaining the causes of monsters and their relation to nature's teleology. ${ }^{78}$ The rest of the Catholic authors do not analyze the portentous meaning at all.

\footnotetext{
${ }^{75}$ See Céard (1996) 3-7. Daston and Park initially (1981) agreed with Céard's opinion but later (1998, 173-177) advocated the coexistence of several sensibilities which overlapped across the centuries. Later studies support this last view. See, for instance, Bates (2005b) 132-134.

${ }^{76}$ On the causal cooperation, see Witmore (2001) 133.

${ }^{77}$ Bates (2005b) 65 and passim ch. 3 had claimed that Protestant narratives were more engaged with the interpretation of monsters as portents than the Catholic accounts. However, his study compares works very different in genre - sixteenth- and seventeenth-century medical learned texts and popular literature - and does not analyze the textbook genre considered in this paper.

${ }^{78}$ Toledo (1580) lib. 2, ca. ix, qu. xiii, fol. $76^{\mathrm{r}}$.
} 
Things were different in the Protestant context, since the function of monsters as portents suited perfectly well with Protestant preoccupation with divine providence. Given that Protestantism maintained, on the one hand, that the recovery of human post-lapsarian depravity depended entirely upon divine mercy and, on the other, did not establish intermediaries linking God with the individual souls, Protestant men and women were anxious to learn whether God had chosen them as elect. Thus, the interpretation of the signs of the divine plan in individuals' lives and in natural events became a central concern and had a wide range of religious, political, and social uses. Within this pattern, rare and extraordinary offspring were regarded as carrying messages concerning individual salvation and collective future. ${ }^{79}$

Accordingly, Protestant textbooks show a greater concern with the theological meaning of monsters as God's signs. Yet, we can recognize that even in these cases the interest was increasingly diminishing toward the end of the sixteenth century. This is noticeable in our selected corpus. If by the middle of the sixteenth century both Velcurio and Melanchthon admitted the value of monsters as portents, by the end of the same century only Case adopted a similar view. ${ }^{80}$ As for Burgersdijck's long and detailed exposition, he judged it necessary to analyze this line of interpretation - so important and widespread in the Protestant world- and to refute it from a strictly "scientific" point of view supported by the following two reasons: on the one hand, it is not always the case that after the generation of a monster, something unusual occurs; on the other hand, there is no verified "physical" connection, neither of monsters as causes nor of monsters as effects with the events allegedly signified by them. ${ }^{81}$ Finally, Keckermann's and Magirus's sketchier treatments - dealing with the essential points of teratology as they were - do not say anything about monsters as portents.

I think that the exceptional position of Case, as compared to the remaining Protestant authors, should be interpreted in the light of peculiarities of the religious, social, and intellectual English background. There, the presence of providentialism was more outstanding than in other Protestant areas, in large part due to the Puritans, which have been called the "hotter sort" of providentialists. ${ }^{82}$ This context might have influenced Case to assert the portentous meaning of monsters.

\footnotetext{
${ }^{79}$ On concepts of providence in early modern Protestantism, see Van der Molen (1978) and Donagan (1981) 385-386.

${ }^{80}$ Velcurio (1558) lib. I, ca. v, 21-22; Melanchton (1565) fol. $152^{\mathrm{v}}$ defines monsters as: "Prodigia [...] seu species, seu res natas praeter naturae ordinem, quae aliquid significant." See also fols. $152^{\mathrm{v}}-155^{\mathrm{v}}$. Goclenius's (1613) 708-709 informed by his irenic attitude as it is, gathers several traditions and presents monsters as preternatural and contranatural facts, much closer to Melanchton's treatment.

${ }^{81}$ Burgersdijck (1643) dis. XXIV, a. 2, i., 261.

${ }^{82}$ I quote the expression of Walsham, who adapting a classic formulation of Patrick Collinson claims - against other interpretations - that providentialism was a mark of Protestantism in general, and not exclusively of Puritanism. See Walsham (1999) 3-4, and passim. For an alternative view, see Thomas (1971), ch. 4, esp. 109. On monsters and providence in England, see, for instance, Walsham (1999) passim and Crawford (2005).
} 


\subsection{Chance, Second Causes, and Providence}

Since Aristotle pointed out that monsters are $\pi \alpha \rho \grave{\alpha} \varphi v ́ \sigma v$ and accidentally caused, many interpreters drew the conclusion that they are produced by chance. Debates on chance became, therefore, an integral part of teratology at least until the eighteenth century. ${ }^{83}$ To the textbook authors, this point was of central interest, for if chance could be considered the cause of monsters, this would be interpreted as a limitation of God's wisdom and power and could even be seen as a suspension of his providence. ${ }^{84}$ Most manuals reduce chance events to causes per se, in the same vein as Melanchthon or Aquinas had done. Melanchthon is very explicit about this; accidental causes, like chance and fortune, derive from at least six kinds of nonaccidental (per se) causes: God and angels, evil spirits, temperaments, celestial tendencies, man's behavior, and matter's instability. ${ }^{85}$ While agreeing with the general attitude of reducing the generation of monsters to non-accidental causes which pursue an end, most textbooks show interesting variations of emphasis in explaining how such a reduction operates.

An extreme position denies the very existence of chance by arguing that God's providence makes it impossible and by strongly emphasizing that every natural phenomenon is submitted to God's plan and rule. No room is given to any level of autonomy in nature's changes, so that nature becomes a mere assistant to divine goals. No wonder, Case represents this stance. He argues that "if God exists, chance does not exist." Although philosophers have claimed that many things in nature happen "contingently according to an unfixed law" (incerta lege contingenter), strictly speaking casus et fortuna are no more than names, since they are not "true and real causes." God's providence may be "latent and occult," but it is "a certain, fixed, and determined cause." Explanations that appeal to chance and fortune are, therefore, spurious and ignorant. Everything acts according to the divine majesty, which had ornamented the world with variety and had "established laws" (legesque sanxit). Thus, he commanded that every individual observe the same order and the law of nature assigned to its species. When a monster is generated, the particular nature makes a mistake, but the universal nature does not. The universal nature, which is singled out by the first cause, is "fixed" by God's providence. To a Christian philosopher, Case concludes, the only "true and real causes" are God and divine providence, nature being God's "minister." 86 Albeit his apparent indifference toward Protestantism or Catholicism, Case argues in a way which approaches the Philippist emphasis on providence, aiming at demonstrating that absolutely everything was

\footnotetext{
${ }^{83}$ On discussions of chance in seventeenth- and eighteenth-century teratology, see, for instance, Bitbol-Hespéries (2005) and Ibrahim (2005) 169-186.

${ }^{84}$ The textbooks talk of fortuna, which is proper to beings which have the capacity to choose, and casus - which corresponds to beings that cannot make choices (to which monsters belong). See Aristotle (1998) II 6, 197a36-198a13.

${ }^{85}$ Kusukawa (1995) 155-157; eadem (2008) 112-113.

${ }^{86}$ Case (1600b) ca. iii, 20; ca viii, 50-55; id. (1600a) lib. 2, ca. viii, 339, 347; lib. 2, ca. vi, 317.
} 
made and ruled by God. ${ }^{87}$ Keckermann seems to endorse a similar view with respect to the last point. Provided that nature is "God's effect or force," both God and nature direct their actions toward a good, which is its end. By the same token, there is no casual action in nature, but every action aims at a fixed and determined goal. ${ }^{88}$

Other authors maintain an intermediate and more nuanced position that, without denying that chance is an accidental cause, claims that, with respect to God's providence, nothing is random. Eustachius defines chance as an accidental cause in those things that happen beyond the intention of the agent and rarely. This is to be considered so only from the human point of view and regarding second causes by themselves. Nonetheless, there is nothing casual with respect to God, who through the straightforward plan of his providence always rules the concurrence of second causes toward the production of their effects. Close to this view, Magirus maintains that sometimes nature is impeded, so that accidentally (by chance) it does not attain the end that it pursues. But again, chance and fortune are accidental causes that must ultimately be reduced to the goals of God's providence. ${ }^{89}$

The Coimbra commentary makes a similar point: chance and fortune are accidental causes, but, with respect to God, nothing occurs fortuitously or randomly since nothing escapes the rule of his providence. As for monsters, its explanation distinguishes between the particular intention of the second causes and the universal intention of the first cause. While it can be said that there is an element of chance regarding the impeded cause, as far as the intention of God is concerned, there can be no chance, given that he is provident and foreknows everything. Similarly, Rubio maintains that monsters are random effects only with respect to the primary intention of natural causes but are not so with respect to their secondary intention. Moreover, there is no natural effect which is purely accidental ("pure casualis, vel omnino per accidens"). Finally, if we understand by nature the first cause, which produces, rules, and directs toward the production of their effects both particular and universal causes, "it is true and necessary that monsters are neither accidental nor random, but per se effects." To support this claim, Rubio - like the Coimbrans and Suárez- appeals to the distinction between God's antecedent and consequent will. ${ }^{90}$ When God concurs with the impeded cause, he wants the regular offspring with his "antecedent and inefficient" will, so that he tends toward the production of a perfect outcome. Nonetheless, his concurrence is "accommodated" to the power of second causes. As a result, when there is an impediment which is stronger than the particular cause aiming the perfect offspring, God wants efficiently (efficaciter $v u l t$ ) the generation of the defective outcome with an "absolute and efficient will."

\footnotetext{
${ }^{87}$ On Melanchthon's view of providence, see Kusukawa (1995)160-162.

${ }^{88}$ Keckermann (1623) lib.1, ca. iv, 18.

${ }^{89}$ Eustachius (1647) Pars Physica, trac. ii, dis. iii, qu. ii, 146-47; Magirus (1646) lib. 1, ca. iii, 51, $55-57$.

${ }^{90}$ On the notions of God's antecedent and consequent will, see above p. 15 of pdf

${ }^{91}$ Conimbricenses (1594) lib. 2, ca. vii, qu. i, art. i, 236-37; Rubio (1629) lib. 2, ca. ix, qu. unica, 286-288. Cf. Suárez (1961) dis. XXIII, sectio 10, n. 11, and Conimbricenses (1594) lib. 2, ca. ix, qu. vi, art. ii, 336 .
} 
Finally, a third stance - represented by Toledo, Pereira, and Burgersdijck diverges a little from the last one, by underlining the role of second causes in the whole analysis. This provides the basis for a more autonomous depiction of nature - a bit closer to the new science - within which natural changes are explained in terms of the intrinsic properties of nature..$^{92}$ Thus, Toledo devotes a long analysis to the notions of chance and fortune and claims that monsters are the result of chance, which is to say that they are effects that accidentally and rarely follow from an "intrinsic natural principle" or "internal cause," for instance, matter. Chance and fortune are accidental efficient causes, whose effects can be called fortuitous or accidental only with respect to particular causes. Although they are not intended by them, they are foreseen by God, and, if they are natural effects, they are pursued by the universal causes (the heavens). Toledo holds that although monstrosities are random effects of particular causes, they are not random with respect to the "universal generator," i.e., the heavenly substances and their motors, "since such matter from which monsters are produced is disposed to such monstrous shape" by celestial influence. ${ }^{93}$ The heavens intend that which is arranged by such a matter, so that from such a matter under certain circumstances, such effect will be necessarily produced.

Toledo's stance shows interesting contrasts with the authors previously considered. In his long treatment of chance and fortune, the words providentia and voluntas do not appear. While he refers very briefly to God's prescience, the core of his argument lies in the analysis of efficient second causes. He agrees with the above examined authors in claiming that monsters are effects of chance only with respect to particular agents, when he adds that in another sense they are not accidental effects. Nevertheless, he relies on celestial influence (rather than on God's providence and will) which lies within the natural world in connection with the necessity proper to efficient causation. His closeness to the later natural philosophical development, however, should not be exaggerated, since divine providence indeed maintains a role in Toledo's depiction of nature. In another question of the same chapter, he endorses the view that everything in nature works for an end and argues that "glorious God" is the one universal and provident cause which has provided to every nature an end. ${ }^{94}$ Once again, we can see that the views of the textbook authors differ in emphasis rather than in substantial contents.

In keeping with this third position, Pereira's stance on chance in monstrous generation is based on nature's operations. Not that he denies that everything in nature is ruled and foreknown by God, but his explanation is more related with second efficient causes. Even longer than Toledo, Pereira devotes the whole book nine of his manual to fortune, chance, and contingence. He makes it clear that it is a very "obscure and ambiguous" question whether in sublunary things there could be a

\footnotetext{
${ }^{92}$ In particular, Jesuits Toledo and Pereira attributed more autonomy to nature with respect to its Creator. For Toledo, see Des Chene (1996) 207-208. For Pereira, see Landucci (2006) ch. 6, esp. 4-84.

${ }^{93}$ Toledo (1580) lib. 2, ca. iv, qu. x, fols. $66^{\mathrm{r}}-69^{\mathrm{v}}$. Ibid., fol. $67^{\mathrm{v}}$.

${ }^{94}$ Ibid., fols. $67^{\mathrm{v}} ; 75^{\mathrm{v}}$.
} 
natural effect said to occur at random with respect to heavenly substances. After exposing arguments pro and contra, he concludes that if the actual concurrence of the heavens is necessary to produce sublunary effects, nothing in the sublunary world can occur randomly with respect to them. Moreover, with respect to God's providence, there is nothing caused by chance and fortune. Only with respect to second and particular causes, it can be said that there are fortuitous and random effects. Consequently, Pereira admits that monsters are produced by chance only in a restrictive sense (secundum quid) as they occur rarely and are not intended as such (per se) but accidentally (per accidens), not on account of something but by the necessity and disorder of matter, which prevents nature from following its ordinary course and forces it to generate another outcome. To Pereira, the more acceptable opinion is the one according to which monsters are not caused by chance, but per se on the basis that their causes are "determined per se, fixed and understood by science." Like Toledo, he maintains that although the causes of monsters are rare, when they are present, the monstrosity necessarily occurs. In fact, once nature is impeded to achieve its end, it turns back all its power and produces monsters. Pereira assumes that every natural effect depends on fixed causes (certae causae) whose time, modes, and other circumstances are prescribed by nature (a natura praefinito constitutae).$^{95}$

An emphasis on second causes is also found in Burgersdijck, who asserts that nature has "its power from another source and employs it not by chance but by a constant and fixed reason." As for the "force" by which nature is led to its end, he rejects as a great ignorance the view that attributes it to matter, chance, and fortune. In contrast, he agrees with Aristotle in ascribing to celestial bodies the power of altering, generating, corrupting, and changing inferior natures. Heavenly bodies move in different ways to distribute this power to inferior bodies. However, since nothing is moved by itself, but by others, the causal series of motion requires a start which consists in an unmoved physical principle. On the other hand, as far as the efficient process is concerned, nature does not tend toward the attainment of its end randomly and disorderly, but with order and skill. This being so, the generation of things is able to be referred to chance and fortune only so far, and that it must ultimately be established that nothing in nature is generated by chance. Burgersdijck admits that monsters can seem to be made by a disorderly nature and at random. Nonetheless, he obscurely argues, they are not nature's intentions, neither can they be attributed to nature as their efficient cause, but by accident. Monsters are works of a nature that is impeded by a hindering force or by matter's incapacity. This seems to mean that nature as a process does not act randomly: monsters do not originate from chance (non temere) but from a determined and fixed end (destinato ac certo fine $)^{96}$

Throughout these three general stances concerning this central point of the discussion of the modal character of monsters, we find a range from an extreme providentialist view of nature (Case) - which heavily subordinates secondary causation to God - to views that give a more prominent role to secondary causation

\footnotetext{
${ }^{95}$ Pereira (1585) lib. 9, ca. ii, 511 and ca. iv, 516; ca. ii, 511; ca. x, 531-532.

${ }^{96}$ Burgersdijck (1643) dis. iv, q. x, 40-41; q. xii, 41-42.
} 
(Toledo, Pereira, and Burgersdijck), passing through an intermediary position in which the cooperation between secondary and primary causation is more equilibrated (Eustachius, Magirus, Rubio, and the Coimbrans).

\subsection{Final Remarks: From "Weak" to "Strong" Laws of Nature}

The textbooks show a preoccupation with the relation of monsters to nature's teleology, but do not express the same concern with their relation to nature's regularity. In these accounts, monsters do not represent a challenge to nature's regularity, since the nomological order includes the possibility of exceptions. Transgressions of the "weak" laws of nature - like monsters - are therefore easily admitted in such a metaphysical framework: both the regular course and the exceptions are part of the world order. For this reason, we do not find any differences in the selected texts regarding this issue.

In contrast, monsters seem to defy the metaphysical tenet that nature always acts toward an end. Hence, the authors seek for arguments to support the view that ultimately monsters are not counterexamples to nature's omnipresent finality. Whereas the textbooks here explored agree in this starting point, they elaborate, however, different argumentative strategies to reconcile the existence of monsters with "strong" finality. The alternative solutions given to the issue of teleology cross the broad Protestant-Catholic divide. That will not come as a surprise, given the high influence that certain Catholic manuals exerted over Protestant Late Scholasticism. One must add, however, that in some cases the preeminence that divine providence had played in Protestantism probably contributed toward the endorsement of the portentous interpretation of monsters recognized in the Oxford scholar John Case curiously suspected of Catholicism- or toward a greater preoccupation with taking a position on this question as manifested by Franco Burgersdijck.

I tried to show that the metaphysical background of the Late Scholastic treatment of monsters combined a "weak" sense of nature's regularity with a "strong" sense of nature's finality. The main concern of these authors was not so much why monsters are irregular, but what the end pursued by them is. Whereas a weak regularity permits exceptions to the generative process of living beings, a strong finality does not admit unintended products of nature. As a result, the existence of monsters was often thought as the articulation of weak laws of nature with ends which are ultimately inescapable: if under certain circumstances some ends cannot be attained, other ends are achieved instead of them. Being the masterpiece of a divine designer, nature always acts toward an end.

Certainly, the assumption of strong finality involved conceptual difficulties for Late Scholastic authors. One symptom of this is the fact that they hardly provide clues about the goals that impeding causes would seek which prevent the completion of regular generation. They only assert that impediments (like anything else in nature) do not tend toward imperfection. Now, if they do not strive for a defective outcome, what do they strive for? Some authors hold that heavens, as universal 
causes, intend monsters. Now, what kind of benefit would defective beings provide to the world? Is diversity/beauty the only good that they can provide? That sounds quite unconvincing, at least to our contemporary eyes. Be that as it may be, it seems that Late Scholastics felt more confident in accounting for the regular ends sought by nature always or for the most part, or even accounting for God's ends, than explaining what good could be provided by nature's defects.

Another uneasy point regards the apparent sufficiency of efficient causes in exhausting scientific explanation, which would entail that appeals to ends are unnecessary. To most of the authors here considered - except perhaps for Case - efficient causes necessitate their effects. However, they still felt the need to dwell on the issue of the intention behind monstrosity to provide a complete scientific explanation of natural effects. The role ascribed to efficient causes and the attention paid to teleology sometimes show tensions inside their stances, particularly in the case of Toledo, Pereira, Keckermann, the Coimbrans, and Burgersdijck. If generation is described as a complex process combining different efficient causes, the postulation of individual, collective, cosmic, or divine ends pursued in the generation process looks like a rather superfluous or even contrived addition to an already satisfactory explanation. The more so when the ultimate teleological reason claims something quite obvious in an orthodox Christian view: every occurrence in nature - a monster as well as whatever regular production- is intended by God. Nonetheless, even if these authors seem to be to a certain point congenial with the path of efficient causes, it remains true that they did not abandon the path of finality, since, as Des Chene has rightly noted, to them it was inconceivable that natural changes should not have ends. ${ }^{97}$ Moreover, they designed a sophisticated doctrine of nature's finality along with a complex hierarchy of ends that could coexist with explanations in terms of efficient causes. Far from assuming a mitigated teleology or no design at all - as Ian Maclean had suggested $-^{98}$ they were still committed to strong finality by appealing to diversified and multilayered kinds of ends. That this commitment to omnipresent teleology increasingly involved hard hermeneutic problems, as the case of monsters remarkably shows, may be one reason for its later and slow decline.

Despite the many changes undergone by natural science and the world picture in the early modern period usually associated with the "Scientific Revolution," the above-studied topics continued to be present well into the eighteenth century in discussions of monsters. At an early stage, for instance, some of them persisted in one of the branches of Francis Bacon's natural history, the "history of pretergenerations." Bacon depicted the facts to be collected in this branch as "the works of nature which have a digression and deflection from the ordinary course of generations, productions, and motions." He also called such works "errors of nature" for which matter was the main culprit: they occur whenever nature is "quite forced to and ripped from its state by the deformities and rarities of obstinate and rebellious matter, and by the violence of impediments." ${ }^{.99}$ Within the Baconian physical and

\footnotetext{
${ }^{97}$ Des Chene (1996) 169.

${ }^{98}$ Maclean (2000) 233.

${ }^{99}$ Bacon (2000) 63 and (1996) 100.
} 
metaphysical framework, the "errors," "impediments," and "rebellious matter" reproduce the Late Scholastic terminology indeed but keep only part of their original meaning.

A generation later, Descartes defied the Late Scholastic narrative even further. In his Primae cogitationes circa generationem animalium (posthumously published in 1701), he explained the birth of hermaphrodites by resorting to secondary material and efficient causes and remarked that these are not "trivial [levis] causes" but actually the most momentous, "the eternal laws of nature."100 Similar nomological explanations of teratogeny became more common throughout the seventeenth and the eighteenth centuries. For instance, Robert Boyle maintained that "when monsters are said to be preternatural things, the expression is to be understood in regard to that particular species from which the monster does enormously deviate, though the causes, that produce that deviation, act but according to the general laws whereby things corporeal are guided." 101 In the same line, Nicolas Malebranche argued that if "a child comes into the world with a malformed head growing from his breast and which makes him wretched (...), it is because [God] has established laws for the communication of motions, of which these effects are necessary consequences." 102 George Berkeley addressed the same issue in holding that "[n]atural productions (...) are not all equally perfect." Moreover, they are explained by "general rules" from whose "constant observation (...) natural evils will some times unavoidably ensue." "103 The explanations of monsters by Descartes, Boyle, Malebranche, and Berkeley did not share the same metaphysical and theological assumptions about causation and the relation of nature to God, but agreed in subordinating monsters to inviolable laws of nature.

Whereas Late Scholastic accounts explained the birth of monsters by claiming that nature's primary and regular intentions were replaced by secondary ones, modern accounts argued that irregular offspring are explained by a set of inviolable laws, distinct from those which applied to regular offspring. However, despite this new nomological approach, older patterns of thought were still an integral part of early modern teratology. The long and intense discussions maintained at the Parisian Académie des Sciences still debated - as Late Scholastic manuals did- whether monsters were exceptions to God's laws of nature and, if so, whether they pursued an end. ${ }^{104}$

Although scholarly studies have shown that there was not a homogeneous view of the laws of nature in early modern natural philosophies, ${ }^{105}$ beyond their common assumptions, early modern philosophers generally thought that laws of

\footnotetext{
${ }^{100}$ Descartes (1909) 523-524; cf. Excerpta, ib. 584.

${ }^{101}$ Boyle (1996) section VII, 109.

${ }^{102}$ Malebranche (1976) vol. V, 32. I quote the English translation Malebranche (1992) 118.

${ }^{103}$ Berkeley (1953) \#256, 121-122. On Malebranche and Berkeley, see Adams (2013) and Schmaltz (2013).

${ }^{104}$ On the querelle des monstres held in the Académie des Sciences's during the seventeenth and eighteenth centuries, see, for instance, Roger (1997) 318-336, Monti (2000), and Bitbol-Hespériès (2012).

${ }^{105}$ See Roux, (2001); Steinle (1995).
} 
nature -being statements that codify regularities observed in nature $-{ }^{106}$ determined a regularity in nature and were applicable without exceptions. ${ }^{107}$ In cases where a phenomenon was not explained by a certain law, it could be explained by other laws, which possessed either the same or greater degree of generality, but which might be unknown to us. Such a view entailed new theoretical difficulties: assuming invariable laws raised the problem of the existence of miracles, insofar as they are interruptions of the regular course of nature. Interruptions within nature - which caused debates long into the late seventeenth and early eighteenth centuries-were not as problematic for late Scholastics.

The Late Scholastic assumption of a purposive nature (strong finality) entailed the possibility of preternatural errors (nature's fallibility) and in large part supported the notion of weak laws of nature admitting exceptions. Hence, one can suggest that the tendency of some relevant trends of the new science to reject the explanatory value of strong view of finality would play as an important concomitant factor, though not the one, permitting the transformation of the concept of laws of nature into exception less regularities. In a program like Descartes' which - consistently or not- eliminates final causes from the scientific explanation, ${ }^{108}$ strong finality is no longer taken for granted, and nature's fallibility does not make sense any more. Against this backdrop, laws of nature may be thought as inviolable and unbreakable.

A broader study will be needed to support this point, but bearing in mind the textbook views here explored, one can suggest that the exception less character of the laws of nature proposed by the natural philosophers who were influenced by this background can be interpreted as a displacement of the strength that Late Scholasticism ascribed to teleology toward natural regularity. In other words, early modern laws of nature assume the regularity and order of nature, but at the same time abandon the teleological framework inherited from Late Scholasticism, either by excluding final causes from scientific explanations, or by arguing that God's ends are beyond the scope of human knowledge, or by suggesting the nonexistence of ends. In this way, the strong character which Late Scholastic textbooks ascribed to teleology was transferred to nature's regularity. ${ }^{109}$ The displacement would lead

\footnotetext{
${ }^{106}$ I follow here John Henry's interpretation, in Henry (2004) 79.

${ }^{107}$ On the exception less character of the laws of nature, see Maclean (2008) 29 and Roux (2001) and eadem (2008) 200.

${ }^{108}$ Descartes (1905) book I \# 28, 15. On Descartes' inconsistencies in his rejection of final causes, see Gaber (1992) 338-339, n. 14.

${ }^{109}$ This reading would provide further evidence in support of Lynn Joy's contentions, which take issue with one of John Milton's claims in Milton (1998). Joy holds two theses: (1) "Aristotle's conception of causal explanation - while in many ways incompatible with explanations based on laws of nature and material efficient causes-actually served as the source of certain definitive features of this modern conception of scientific explanation"; (2) "the decline of explanations in terms of the four causes occurred not because the new conception of scientific explanation was shown to be rationally superior to Aristotle's conception but because the latter had been seriously weakened by the efforts of its early modern defenders to rehabilitate it." See Joy (2006) 73 (italics in the original).
} 
Descartes and others finally to refuse the inherited concept of monsters, by showing that, after all, they are not errors at all, but natural events in accordance with exception less laws of nature.

Acknowledgment I would like to thank Koen Vermeir, John Henry, Jonathan Regier, and Gabriela Rossi for their helpful comments on earlier versions of this paper.

\section{Bibliography}

\section{Primary}

Aristotle. 1476. De animalibus [...]. Trad. Theodoro Gaza. Venice: Johan de Colonia and Johan Manthen.

-1560. Aristotelis Stagiritae libri omnes ad animalium cognitionem attinentes, cum Averrois Cordubensis variis in eosdem commentariis [Aristotelis opera cum Averrois commentariis]. Trad. Theodore Gaza. Venice: Giunta. Reprint Frankfurt am Main: Olms, 1962.

Aristoteles Latinus. 1966. De generatione animalium. Trans. William of Moerbeke. ed. Hendrik Joan Drossaart Lulofs. Leiden: Brill.

Aristotle. 1992. De animalibus: Michael scots Arabic-Latin translation, part three, books XVXIX, Generation of Animals, Vol. 5 of Aristotles Semitico-Latinus. ed. Aafke M. I Van Oppenraaij. Leiden: Brill.

- 1998 [1936]. Physics, ed. D. Ross. Oxford: Clarendon Press.

. 2000 [1942]. Generation of Animals, ed. Arthur Leslie Peck. London/Cambridge: Harvard University Press.

Bacon, Francis. 1996. Descriptio globi intellectuallis. In The Oxford Francis Bacon, ed. Graham Rees, vol. VI. Oxford: Clarendon Press.

2000. The advancement of learning. In The Oxford Francis Bacon, ed. Michael Kiernan, vol. IV. Oxford: Clarendon Press.

Berkeley, George. 1953. Siris (1744). In The Works of George Berkeley, Bishop of Cloyne, ed. A.A. Luce and T.E. Jessop, vol. V. London: Thomas Nelson and Sons.

Boyle, Robert. 1996. A Free Enquiry into the Vulgarly Received Notion of Nature (1686), ed. Edward B. Davis and Michael Hunter. Cambridge: Cambridge University Press.

Burgersdijck, Franciscus. 1645 [1622]. Idea philosophiae naturalis sive methodus definitionum et controversiarum physicarum. Leiden: Elzevier.

Burgersdijck, Franconus. 1643. Collegium physicum disputationis XXXII [...]. Leiden: Elzevier.

Case, John. 1600a [1599]. Lapis philosophicus sive Commentarius in octo libros Physicorum Aristotelis [...]. Frankfurt: A. Wechsel and A. Hierat. 1600b. Ancilla philosophiae, seu epitome in octo Libros physicorum Aristotelis. Frankfurt: Andreas Wechel.

Chauvin, Étienne. 1692. Lexicon rationale sive thesaurus philosophicus [...]. Rotterdam: P. van der Slaart.

Conimbricenses. 1594 [1592]. Commentariorum Collegii Conimbricensis Societatis Jesu, in octo Libros Physicorum Aristotelis Stagiritae, Vol. 1. Cologne: Zeztner. Reprint Hidelsheim: Olms, 1984.

Damascene, John. 1955. De fide orthodoxa. Versions of Burgundio and Cerbanos, ed. Eligius Buytaert. St. Bonaventure: The Franciscan. Inst., et al.

de Carvalho, Mário Santiago. 2011. Introdução. In Comentários a Aristóteles do Curso Jesuíta Conimbricense 1592-1606. Antologia de Textos. Trads. A. Banha de Andrade, Maria da Conceição Camps, Amândio A. Coxito, Paula Barata Dias e Filipa Medeiros, 1-13. Coimbra: LIF - Linguagem, Interpretacao e Filosofia, Faculdade de Letras. 
Descartes, René. 1905. Principia philosophiae. In Oeuvres de Descartes, ed. Charles Adam and Paul Tannery, vol. VIII. Paris: Léopold Cerf.

- 1909. Primae cogitationes circa generationem animalium. In Charles Adam and Paul tannery, ed. Oeuvres de Descartes, vol. XI. Paris: Léopold Cerf.

Eustachius a Sancto Paulo. 1647 [1609]. Summa philosophiae quadripartita, De rebus dialecticis, ethicis, physicis et metaphysicis. Leiden: F. Moyardus.

Goclenius, Rudolph. 1613. Lexicon philosophicum. Frankfurt: Matthias Becker.

Keckermann, Bartholomeus. 1623/1607. Systema physicum. Hannover: P. Antonius.

Magirus, Johannes. 1646 [1597]. Physiologiae Peripateticae libri sex cum commentariis. Frankfurt: Bringer.

Malebranche, Nicolas. 1976. Traité de la nature et de la grâce (1680). In Euvres complètes de Malebranche, ed. Andrè Robinet, vol. V. Paris: Vrin. English edition: Malebranche, Nicolas. 1992. Treatise on Nature and Grace. Trans. Patrick Ryle. Oxford: Clarendon Press.

Melanchton, Philip. 1565. Initia doctrinae physicae. Wittenberg: J. Crato.

Pereira, Benedictus. 1585 [1576]. De communibus omnium rerum naturalium principiis et affectionibus libri quindecim, qui plurimus conferunt, ad eos octo libros Aristotelis, qui de Physico auditu inscribuntur, intelligendos. Lyon: Porta.

Rubio, Antonius. 1629. Commentarii in octo libros Aristotelis De Physico Auditu. Cologne: I. Crithius, sub signo Galli.

Suárez, Francisco. 1961/1597. Disputaciones metafísicas. Edición bilingüe. Ed. and trans. S. R. Romeo, S. C. Sánchez and A. Puigcerver. Madrid: Gredos.

Thomas Aquinas. 1975. Summa contra gentiles, 5 vols. Notre Dame: University of Notre Dame Press.

Toledo, Franciscus. 1580 [1573]. Commentaria una cum quaestionibus in octo libros Aristotelis De Physica Auscultationibus. Venice: Iuntas.

Velcurio, Johannes. 1538. Epitomae physicae libri quator. Erfurt: M Saxo. 1558 [1540]. Commentariorum libri iiii in Aristotelis Physicen. London: Th. Paganus.

\section{Secondary}

Adams, Robert Merrihew. 2013. Malebranche's Causal Concepts. In The Divine Order, the Human Order, and the Order of Nature: Historical Perspectives, ed. Eric Watkins, 67-104. Oxford: Oxford University Press.

Ariew, Roger. 2003. Descartes and the Jesuits: Doubt, Novelty, and the Eucharist. In Jesuit Science and the Republic of Letters, ed. Mordechai Feingold, 157-207. Cambridge, MA: MIT Press.

Bates, Alan W. 2005a. Good, Common, Regular, and Orderly: Early Modern Classifications of Monstrous Births. Social History of Medicine 18: 141-158.

- 2005b. Emblematic Monsters: Unnatural Conceptions and Deformed Births in Early Modern Europe. Amsterdam: Rodopi.

Beullens, Pieter, and Alan Gotthelf. 2007. Theodore Gaza's translation of Aristotle's De Animalibus: Content, Influence, and Date. Greek, Roman, and Byzantine Studies 47: 469-513.

Bitbol-Hespériès, Annie. 2005. Conjoined Twins and the Limits of Reason. In Monsters and Philosophy, ed. Charles Wolfe, 61-108. London: College Publications.

. 2012. Monsters, Nature, and Generation from the Renaissance to the Early Modern Period: The Emergence of Medical Thought. In The Problem of Animal Generation in Early Modern Philosophy, ed. Justin E.H. Smith, 47-62. Cambridge: Cambridge University Press.

Blum, Paul Richard. 2006. Benedictus Pererius: Renaissance Culture at the Origins of Jesuit Science. Science \& Education 15: 279-304.

Canguilhem, Georges. 2008. Knowledge of life. New York: Fordham University Press Translation of the French edition, 1992, La connaissance de la vie.

Céard, Jean. 1996. La nature et les prodiges. L'insolite au XVIe. Siècle. 2nd ed. Genève: Droz. 
Copenhaver, Brian P., and Charles Schmitt. 1992. Renaissance Philosophy. A History of Western Philosophy. Vol. III. Oxford/New York: Oxford University Press.

Crawford, Julie. 2005. Marvelous Protestantism: Monstrous Births in Post-Reformation England. Baltimore/London: The John Hopkins University Press.

Daston, Lorraine. 2004. Nature's Customs versus Nature's Laws. The Tanner Lectures on Human Values 24: 392-412.

Daston, Lorraine, and Katherine Park. 1981. Unnatural Conceptions: The Study of Monsters in Sixteenth-and Seventeenth Century France and England. Past and Present 28: 20-54. . 1998. Wonders and the Order of Nature, 1150-1750. New York: Zone Books.

Davies, Sureka. 2013. The Unlucky, the Bad and the Ugly: Categories of Monstrosity from the Renaissance to the Enlightenment. In Ashgate Research Companion to Monsters and the Monstrous, ed. Asa Simon Mittman, 49-75. Farnham: Ashgate.

Des Chene, Denis. 1996. Physiologia: Natural Philosophy in Late Scholastic and Cartesian Thought. Ithaca: Cornell University Press.

Donagan, Barbara. 1981. Providence, Chance, and Explanation: Some Paradoxical Aspects of Puritan Views of Causation. Journal of Religious History 11: 385-403.

Flower, Elizabeth. 1988. Harvard. In Grundriss der Geschichte der Philosophie. Die Philosophie des 17. Jahrhunderts, ed. Jean-Pierre Schobinger, vol. III/1, 19-25. Basel: Schwabe.

Freedmann, Joseph. 1997. The Career and Writings of Bartholomew Keckermann. Proceedings of the American Philosophical Society 3: 305-364.

Gaber, Daniel. 1992. Descartes Metaphysical Physics. Chicago/London: The University of Chicago Press.

Guidi, Simone. 2012. Errata naturae. Cause prime e seconde del mostro biologico tra medioevo ed età moderna. Lo sguardo. Rivista di filosofia 9: 65-105.

Hanafi, Zakiya. 2000. The Monster in the Machine: Magic, Medicine and the Marvelous in the Time of the Scientific Revolution. Durham: Duke University Press.

Henry, John. 2004. Metaphysics and the Origins of Modern Science: Descartes and the Importance of Laws of Nature. Early Science and Medicine 9: 73-114.

Hotson, Howard. 2002. Philosophical Pedagogy in Reformed Central Europe between Ramus and Comenius: A Survey of the Continental Background of the Three Foreigners. In Samuel Hartlib and Universal Reformation, ed. Mark Greengrass and Michael Leslie, 29-50. Cambridge: Cambridge University Press.

- 2007. Commonplace Learning: Ramism and Its German Ramifications 1543-1630. Oxford: Oxford University Press.

Ibrahim, Annie. 2005. The Status of Anomalies in the Philosophy of Diderot. In Monsters and Philosophy, ed. Charles Wolfe, 169-185. London: College Publications.

Joy, Lynn. 2006. Scientific Explanation from Formal Causes to Laws of Nature. In The Cambridge History of Science. Vol. 3: Early Modern Science, ed. Katharine Park and Lorraine Daston, 70-105. Cambridge: Cambridge University Press.

Krop, H. 2011. Burgersdijk, Franck Pieterszoon. In The Continuum Companion to Spinoza, ed. Wiep van Bunge and others, 60-62. London: Continuum.

Kusukawa, Sachiko. 1995. The Transformation of Natural Philosophy: The Case of Philip Melanchthon. Cambridge: Cambridge University Press.

2008. Nature's regularity in some protestant natural philosophy textbooks $1530-1630$. In Natural Law and Laws of Nature in Early Modern Europe Jurisprudence, Theology, Moral and Natural Philosophy, ed. Lorraine Daston and Michael Stolleis, 105-142. Farnham: Ashgate.

Landucci, Sergio. 2006. I filosofi e Dio. Roma-Bari: Laterza.

Lohr, Charles. 2000. Metaphysics. In The Cambridge History of Renaissance Philosophy, ed. Charles B. Schmitt and Quentin Skinner, 537-638. Cambridge: Cambridge University Press.

Mack, Peter. 2011. A History of Renaissance Rhetoric 1380-1620. Oxford: Oxford University Press.

Maclean, Ian. 2000. Evidence, Logic, the Rule and the Exception in Renaissance Law and Medicine. Early Science and Medicine 5: 227-257. 
2007. Logic, Signs and Nature in the Renaissance: The case of Learned Medicine. Cambridge: Cambridge University Press.

- 2008. Expressing Nature's Regularities and Their Determinations in Late Renaissance. In Natural Law and Laws of Nature in Early Modern Europe Jurisprudence, Theology, Moral and Natural Philosophy, ed. Lorraine Daston and Michael Stolleis, 29-44. Farnham: Ashgate. 2012. Scholarship, Commerce, Religion. The Learned Book in the Age of Confessions, 1560-1630. Cambridge, MA: Harvard University Press.

Manzo, Silvia. 2013. The Preservation of the Whole and the Teleology of Nature in Late Medieval, Renaissance and Early Modern Debates on the Void. Journal of Early Modern Studies 2 (2): 9-34.

Monti, Maria Teresa. 2000. Epigenesis of the Monstrous Form and Preformistic Genetics: LémeryWinslow-Haller. Early Science and Medicine 5: 3-32.

Milton, John. 1998. Laws of nature. In The Cambridge History of Seventeenth-Century Philosophy, ed. Daniel Garber and Michael Ayers, vol. 1, 680-701. Cambridge: Cambridge University Press.

Osorio Romero, Ignacio. 1988. Antonio Rubio en la filosofía novohispana. México: UNAM, Instituto de Investigaciones Filológicas.

Panti, Cecilia. 2013. Natura non intendit nisi quinque digitos. Caso, contingenza e mostruosità nelle questiones supra Octo libros physicorum e nei communia naturalium. Rivista di storia della filosofia 1: 101-130.

Perfetti, Stefano. 2000. Aristotle's Zoology and its Renaissance Commentators 1521-1602. Leuven: University of Leuven Press.

Reif, Patricia. 1964. Natural Philosophy in Some Early Seventeenth-Century Scholastic Textbooks. $\mathrm{PhD}$ dissertation, St. Louis University.

1969. The Textbook Tradition in Natural Philosophy, 1600-1650. Journal of the History of Ideas 30: 17-32.

Roger, Jacques. 1997. The Life Sciences in Eighteenth-Century French Thought, ed. Keith R. Benson. Trans. Robert Ellrich. Stanford: Standford University Press. From the 2nd French ed., 1993.

Rogers, G.A. John. 1988. Cambridge. In Grundriss der Geschichte der Philosophie. Die Philosophie des 17. Jahrhunderts, ed. Jean-Pierre Schobinger, vol. III/1, 10-12. Basel: Schwabe.

Rossi, Gabriela. 2011. El azar según Aristóteles: Estructuras de la causalidad accidental en los procesos naturales y en la acción. Sankt Augustin: Academia-Verlag.

Roux, Sophie. 2001. Les lois de la nature à l'âge classique: la question terminologique. Revue de Synthèse 122: 531-576.

- 2008. Controversies on Nature as Universal Legality 1680-1710. In Natural Law and Laws of Nature in Early Modern Europe Jurisprudence, Theology, Moral and Natural Philosophy, ed. Lorraine Daston and Michael Stolleis, 199-214. Farnham: Ashgate.

Rüstow, Edward G. 1973. Physics at Seventeenth and Eighteenth-Century Leiden: Philosophy and the New Science in the University. The Hague: M. Nijhoff.

Schmaltz, Tad. 2013. Laws and Order: Malebranche, Berkeley, Hume. In The Divine Order, the Human Order, and the Order of Nature: Historical Perspectives, ed. Eric Watkins, 105-126. Oxford: Oxford University Press.

Schmitt, Charles B. 1983a. Aristotle and the Renaissance. Cambridge, MA: Harvard University Press.

—. 1983b. John Case and Aristotelianism in Renaissance England. Kingston: McGill-Queens University Press.

Steinle, Friedrich. 1995. The Amalgamation of a Concept. Laws of Nature in the New Sciences. In Laws of Nature. Essays on the Philosophical, Scientific, and Historical Dimensions, ed. Friedel Weinert, 316-368. Berlin: De Gruyter.

. 2001. Von a-priori-Einsichten zu empirischen Regularitäten: Der Gesetzesbegriff und seine Alternativen in der frühen Royal Society. In Studia Leibnitiana - Sonderheft 31: Kausalitat und Naturgesetz in der fruhen Neuzeit, ed. Andreas Huttemann, 77-98. Stuttgart: Steiner. 
Thomas, Keith. 1971. Religion and the Decline of Magic. New York: Scribner.

Van der Molen, Ronald. 1978. Providence as Mystery, Providence as Revelation: Puritan and Anglican Modifications of John Calvin's Doctrine of Providence. Church History 47: 27-47.

Wallace, William. 2000. Traditional Natural Philosophy. In The Cambridge History of Renaissance Philosophy, ed. Charles B. Schmitt and Quentin Skinner, 201-235. Cambridge: Cambridge University Press.

Walsham, Alexandra. 1999. Providence in Early Modern England. Oxford: Oxford University Press.

Weill-Parot, Nicolas. 2012. Retour sur l'horreur du vide. Les origines de la nature universelle dans la physique médiévale et ses significations XIIIe-XIVe siècle. In La nature et vide dans la physique médiévale, ed Joël Biard et Sabine Rommevaux, 15-38. Turnhout: Brepols.

Weinert, Friedel. 1995. Introduction. In Laws of Nature: Philosophical, Scientific and Historical Dimensions, ed. Friedel Weinert, 4-14. Berlin: de Gruyter.

Witmore, Michael. 2001. Culture of Accidents Unexpected Knowledges in Early Modern England. Stanford: Stanford University Press. 